\title{
Assessment of spatial variability of environmental conditions in different swine production typologies in tropical conditions
}

\author{
Jairo Alexander Osorio Saraz ${ }^{\mathrm{a} *}$ (D) | Natalia Castrillon Mejia ${ }^{\mathrm{bc}}$ (iD) | Veronica Gonzalez Cadavid ${ }^{\mathrm{ac}}$ (D) | \\ Yesica Paola Quintero Soto ${ }^{\mathrm{b}}$ | $\mid$ Ana Paola Montoya Rios ${ }^{\mathrm{a}}$ (D) | Eugenia González Castrillon ${ }^{\mathrm{a}}$ \\ aniversidad Nacional de Colombia, Sede Medellín, Facultad de Ciencias Agrarias, Carrera 65 \#59A-110, Código postal Co050034 Medellín, Colombia. \\ Universidad Nacional de Colombia, Sede Medellín, Facultad de Minas, AV 80 \#65-223, Código postal CO050034 Medellín, Colombia \\ 'Grupo de Investigación en Biodiversidad y Genética Molecular (BIOGEM), Departamento de Producción Animal, Universidad Nacional de Colombia, Sede \\ Medellín, Carrera 65 No. 59 A-110, C0050034 Código, Colombia.
}

Corresponding author: aosorio@unal.edu.co

\begin{abstract}
Comfort index and environmental variables are indicators of thermal stress conditions inside a livestock facility. The environmental conditions of ten different constructive typologies of swine-production facilities with natural ventilation were characterized in a tropical country (Antioquia, Colombia). Temperature and humidity index $(T H I)$, enthalpy $(H)$, animal surface temperature (ST), light intensity, and noise level were measured and computed for each typology, which were located at heights above sea levels between 8:00-23:00. Data was analyzed as a function of each typology, geographical altitude, and time of the day. It was employed descriptive statistics, analysis of variance, and contour maps to analyze the data. It was found that more than $80 \%$ of the typologies presented moderate or critical stress conditions associated with the construction typology, not suitable $T H I$ and light intensity values, especially in warm and mild-mild climates. Showing high special variability inside the facilities. New typological designs and bioclimatic conditioning for swine facilities need to be studied To be implemented in these climatic conditions.
\end{abstract}

Keywords animal welfare, comfort index, pig production, thermal stress

\section{Introduction}

In swine production, correctly planning a shelter's design and construction can guarantee the animals space according to their vital requirements, welfare and ensure efficient meat production. (Kiefer et al 2010; Machado et al 2016; Cecchin et al 2018; Cecchin et al 2019). Pigs are considered homoeothermic animals; this means that they withstand specific body temperature conditions, when that value exceeds the limit, the animal begins to have behavior and health problems (Barreto et al 2010; Barbari \& Conti 2009).

The thermal environment directly influences the heat exchange between the pig and its surrounding environment. The main variables that positively or negatively affect the environment are temperature, air velocity, illumination, gases concentration, and relative humidity (Carvalho et al 2014; Machado et al 2016). For animal species, there is a thermal environment where maximum productivity occurs, characterized by these variables, that desirable condition is called the "thermal comfort-zone of the animal" (dos Santos et al 2018).

There is a predetermined thermal comfort-zone range suggested by several authors, if these conditions are suitable, it could guarantee that the production is efficient and that the normal physiological conditions of the animal are not altered
(Barreto et al 2010 and Carvalho et al 2014). This comfort zone depends on filo, age, weight, sex, quantity, and feed quality, mainly. A pig under thermal stress can trigger physiological adjustments so that its body temperature remains constant (Ramos et al 2017; Roller and Goldmn 1969). These adjustments have implications for reducing food consumption and decreasing productivity (Vieira et al 2010).

Recently, other variables have been studied to complement those related to the thermal environment, such as sound pressure, light intensity and gas emissions, researches that have been carried out in different animal facilities (Schiassi et al 2012; Ferraz et al 2020; Castrillon et al 2020).

In tropical regions, the climate is the main determining factor that limits animals' maximum performance due to the stress that high temperatures can trigger (Toniolli et al 2014; Machado et al 2016). This is why housing plays a fundamental role; therefore, it is necessary to have a design that complies with the basic principles of bioclimatic architecture and considers a set of environmental variables that guarantee an appropriate space for the animal that does not depend on mechanical systems.

To characterize and identify the suitable thermal comfort zones for the swine species, thermal comfort indices are developed. It should be noted that, these conditions have also been studied in other species such as birds and cattle. 
The comfort index is represented by a dimensionless value, that characterize the animal's surrounding thermal environment, while providing information about the environment and the stress it is may be generating.

The construction typology in a pig farm can condition its thermal environment, as several studies have shown (Machado et al 2016; Cecchin et al 2017). The type of floor, the sewer conduction system, the lateral structure, and the ventilation on the roof (like others), can condition the thermal environment, which can be assessed through some indexes.

In Colombia, the subject has been little explored. There is no standard typological classification that allows knowing which typology is the most suitable for each specific animal production condition (Castrillon et al 2020). That is why this work aimed to evaluate the thermal environment distribution of pig farms with different construction typologies with natural ventilation, located in the state of Antioquia - Colombia, a region that concentrates around $40 \%$ of pig production nationwide (ICA 2019).

\section{Materials and Methods}

\subsection{Location and characterization of the study area}

The study area was located in the department of Antioquia in Colombia. This territory concentrates the largest production of pigs nationwide (Vélez et al 2018; ICA 2019). Ten fattening pig commercial farms were randomly selected. Facilities were located from 800 to 2300 meters above the sea level (MASL), which were classified in three thermal floors (Warm 0-1000 MASL; Mild 1001-2000 MASL; Cold 2001-3000 MASL) based on the weather model of Caldas lang and according to ICA 002640 of 2007 (Colombian regulations resolution). They are considered technician farms or that their production includes a set of guidelines such that quality production is guaranteed. The data associated with the farms, such as typology, date of visit, municipality, orientation, type of ventilation, construction materials, and height above sea level, are detailed in Table 1.

Table 1 Description of the different constructive typologies.

\begin{tabular}{llcclcc}
\hline Typology & Orientation & MASL & $\begin{array}{c}\text { Thermal } \\
\text { floor }\end{array}$ & Roof Features & $\begin{array}{c}\text { Ventilation ratio } \\
\text { Area/Total Area }\end{array}$ \\
\hline I & W-E & 2174 & Cold & Open Ridge ventilation and Clay Tiles. & 0.14 \\
\hline II & N-S & 1179 & Mild & Without Open ridge Ventilation and Eternit \\
& & & Tiles. & 0.44 \\
\hline III & N-S & 1481 & Mild & Open Ridge ventilation and Eternit Tiles. & 0.39 \\
\hline IV & W-E & 2202 & Cold & Without Open Ridge and Concrete roof & 0.16 \\
\hline V & N-S & 1504 & Mild & Without Open Ridge and Concrete roof & 0.12 \\
\hline VI & N-S & 816 & Warm & Open Ridge Ventilation and Zinc Tiles & 0.39 \\
\hline VII & N-S & 1732 & Mild & Open Ridge Ventilation and Zinc Tiles & 0.33 \\
\hline VIII & W-E & 2263 & Cold & Open Ridge Ventilation and Eternit Tiles & 0.13 \\
\hline IX & N-S & 1408 & Mild & Open Ridge Ventilation and Eternit Tiles & 0.36 \\
\hline X & N-S & 1000 & warm & Open Ridge Ventilation and Zinc Tiles & 0.28 \\
\hline
\end{tabular}

\subsection{Characteristics of the animals evaluated}

The pigs of the farms under study were in the fattening productive stage with an average weight between $60-80 \mathrm{~kg}$, separated male females, and the density of animals per square meter was similar in all facilities. Their primary food was the same commercial concentrate for all the farms evaluated, and they had all the necessary equipment. Feed and water ad libitum through feeders and drinking troughs, where feeders were recharged three times a day. The dry area was differentiated from the wet one, and aeration was regulated through natural ventilation.

\subsection{Experimental development}

Field visits were made between June and August of 2019 , in a dry period with some isolated rainfalls, according to the climatic characteristics proposed by Poveda (2004).
For the data collection, the method of subdivision by points or systematic sampling was used. The area of the shed, with its dimensions (length $x$ width) in meters, was divided into grids ( 3 - 4 spaces across the width and $5-7$ spaces throughout in length, depending on the size of the module, where each space had a surface area of 2 meters), and in each one, a measuring point was located, to take representative samples throughout the installation area (Figure 1). In total, 18 points were established for each typology.

The time measurement range was established for 12 hours, from 6:00 am to 6:00 pm, with measurement intervals of three hours during the day at 6:00, 9:00, 12:00, 15:00 and 18:00 hours, with three repetitions. This is to have a sampling throughout the day, when the greatest thermal variability occurs, the most significant peaks of high and low temperatures. 
Different typologies were classified by thermal floor, as shown in Table 2, where the most significant number of typologies farms are found in mild climates, according to the reality of Colombian pig farming.
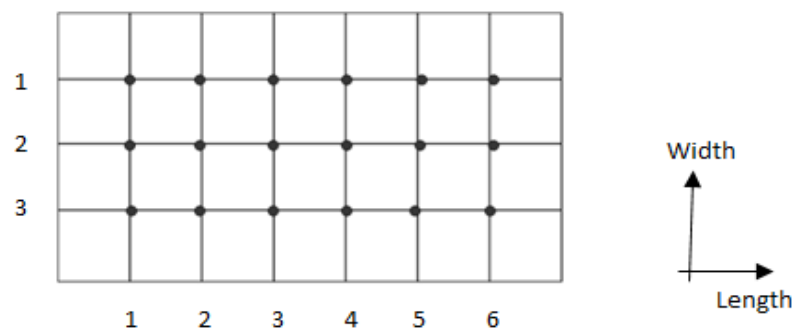

Figure 1 Typical scheme of distribution of sampling points in the facilities.

\subsection{Variables and Thermal comfort index for pigs}

The dry bulb temperature $\left(T_{d b}\right)$, relative humidity $(R H)$ (HD32.2, Delta OHM), pig surface temperature ear based (ST) that was measurement with the thermal camera (Ti400, Fluke Corporation), light intensity (Ix) (DT3809-, CEM), noise (db) (DT-815, CEM), enthalpy $\left(H-\mathrm{kJ}^{\mathrm{kg}} \mathrm{kg}^{-1}\right)$ and the Temperature Humidity Index (THI) were measurement and calculated in each point during the experiment in the different typologies.

The $T H I$ was calculated using equation 1, proposed by Thom et al (1958) (Bureau of Meteorology 2005; Zanetoni et al 2019).

$T H I=T H I=T_{d b}+0.36 T_{d p}+41.2$

where $T_{d b}$ and $T_{d p}$ - are the dry and wet bulb temperature $\left({ }^{\circ} \mathrm{C}\right)$, respectively.

$H$ was calculated using equation 2 , according to Barbosa Filho et al (2009), to characterize the thermal environment inside the facilities.

$H=6.7+0.243 T_{d b}+\left(\frac{R H}{100 * 10^{\frac{7.5 T}{237.3 T} d b}}\right)$

where $H$ - is enthalpy ( $\mathrm{kcal} / \mathrm{kg}$ of dry air), $T_{d b}$ - dry bulb temperature $\left({ }^{\circ} \mathrm{C}\right), R H$ - relative air humidity (\%). These variables and the index allow to evaluate the thermal comfort inside the pig installations and characterize the environment to which the animals are subjected to analyze if these conditions of comfort are favorable or not for their productive performance.

The reference values adopted by various authors to determine the comfort or discomfort condition were used such us: Amaral et al (2020), Zanetoni et al (2019), Damasceno et al (2019), de Oliveira Júnior et al (2018), Zonderland et al (2008). Also, reference values for temperature and relative humidity, recommended to prevent the pig from being in a stress condition in its different physiological stages, are established (Tables 3 and 4).
Table 2 Classification of typologies according to the thermal floor.

\begin{tabular}{lc}
\hline Thermal Floor (MASL) & Tipology \\
\hline Warm (0 - 1000) & VI, X \\
\hline Mild(1000-2000) & II, III, V, VII, IX \\
\hline Cold (2000-3000) & I, IV, VIII \\
\hline
\end{tabular}

\subsection{Equipment used}

Different equipments were required to measure the variables evaluated. The commercial names and the technical characteristics associated with the instruments are described in Table 5. The equipment was supplied by the Bioclimatic Laboratory of the Universidad Nacional de Colombia Medellin Campus. Before collecting the information, the equipment was calibrated in the laboratory.

Table 3 Thermal comfort limits for pigs.

\begin{tabular}{ll}
\hline Noise $(\mathrm{db})$ & Noise $<70$ \\
\hline Comfort & $70 \leq$ Noise $\geq 85$ \\
\hline Discomfort & Noise $>85$ \\
\hline Stress & \\
\hline THI & THI $\leq 74$ \\
\hline Thermal comfort & $75 \leq \mathrm{THI}<79$ \\
\hline Alert & $79 \leq \mathrm{THI}<84$ \\
\hline Dangerous & $\mathrm{THI} \geq 84$ \\
\hline Emergency & \\
\hline Light (Lux) & $\mathrm{Ix} \geq 40$ \\
\hline Comfort & $\mathrm{Ix}<40$ \\
\hline Discomfort & \\
\hline
\end{tabular}

Table 4 Optimal range to $\mathrm{T}_{\mathrm{db}}$, $\mathrm{RH}$ and $\mathrm{H}$ for fattening pigs.

\begin{tabular}{ccc}
\hline $\begin{array}{c}\text { Ideal } \mathrm{T}_{\mathrm{db}}\left({ }^{\circ} \mathrm{C}\right) \\
\text { max-min }\end{array}$ & $\begin{array}{c}\text { Ideal relative } \\
\text { humidity } \mathrm{RH}(\%)\end{array}$ & $\begin{array}{c}\text { Enthalpy } \mathrm{H}\left(\mathrm{kJ}^{\mathrm{k}} \mathrm{kg}^{-1}\right) \\
\text { (Moura 1999) }\end{array}$ \\
$18-12$ & $50-70$ & $60.44-68.62$ \\
\hline
\end{tabular}

\subsection{Statistical analysis}

The information collected was subjected to an analysis of variance (ANOVA) to evaluate the values of the $T H I, H, T_{d b}$, $R H$, Light and Noise concentration and their differences in thermal floors relationship, identified for each construction typologies, using the statistical software R. The means were compared using the Tukey's test with a significance level of $P$ $<0.05$ for all cases.

The variables' spatial variability through the experiment was analyzed by semivariogram fitting and ordinary kriging interpolation (equation 3 ):

$\hat{\gamma}(\mathrm{h})=\frac{1}{2 \mathrm{~N}(\mathrm{~h})} \sum_{\mathrm{i}=1}^{\mathrm{N}(\mathrm{h})}\left[\mathrm{Z}\left(\mathrm{x}_{\mathrm{i}}\right)-\mathrm{Z}\left(\mathrm{x}_{\mathrm{i}}+\mathrm{h}\right]^{2}\right.$ 
where $N(h)$ is the number of experimental observation pairs, $Z(x i)$ and $Z(x i+h)$, separated by a distance, $h$.

The semivariogram was fitted using the restricted maximum likelihood (REML) method. The mathematical model used to fit the semivariogram was the spherical model.

\section{Results and Discussion}

Table 6 shows the average values for $T_{d b}, R H, S T$, Light, Noise, $H$ and $T H I$ indices for the construction typologies. The same letter in a columm means no significant differences in the variable for the typologies. The relative humidity were found between 57 to $76 \%$ in different thermal floors and was above the optimal values for typologies I and II. The temperature was higher on the warm thermal floors, as is logical. The highest THI was found in the warm floor's typologies, followed by the II and IX in mild one. Therefore, was found that almost all the facilities had $T H I$ and $H$ above the comfort limiting conditions according to Table 3, excepting the IV and VIII facilities in cold and III in the mild floor. There are not significant differences with the ST; however, the highest values are in the warm and mild floor. It was found that almost all typologies had a good light intensity except typologies I and IV, which have light intensity below $40 \mathrm{Ix}$. The typologies $\mathrm{VI}$ and $\mathrm{X}$ in warm, thus II in the mild floor, were the facilities with noise levels over 70, resulting in discomfort conditions.

Although no correlation was found between the $T H I$ and the $S T$, it is observed that the higher ST are associated with the typologies with mayor $T H I$ for the warm and mild floor. The ST range for the warm and mild floor typologies was $34.08 \pm 1.58$ to $35.77 \pm 2.54{ }^{\circ} \mathrm{C}$, which agrees with what was found by Resquejo et al (2018), who carried out ST measurements in pigs subjected to alert thermal stress conditions, reporting a ST range of $32.82 \pm 2.29$ to $35.89 \pm 1.50$ ${ }^{\circ} \mathrm{C}$. The results lead to infer that $S T$ can indicate the thermal discomfort to which the pork is subjected. More extensive research in the matter need to be done to be conclusive.

Table 5 Equipment used.

\begin{tabular}{|c|c|c|}
\hline Equipment & & Accuracy and precision \\
\hline $\begin{array}{l}\text { Windsonic Ultrasonic Wind } \\
\text { sensor (anemometer) }\end{array}$ & Wind speed and bi-directional wind direction & $\begin{array}{c}\text { Wind Speed } \\
\text { Range } 0-60 \mathrm{~m} / \mathrm{s} \\
\text { Accuracy } \pm 2 \% @ 12 \mathrm{~m} / \mathrm{s} \\
\text { Resolution } 0.01 \mathrm{~m} / \mathrm{s}(0.02 \text { knots) } \\
\text { Response Time } 0.25 \text { seconds } \\
\text { Threshold } 0.01 \mathrm{~m} / \mathrm{s}\end{array}$ \\
\hline Thermo-hygrometer & Temperature Humidity Relative $\left({ }^{\circ} \mathrm{C}, \%\right)$ & $\begin{array}{c}\text { Temperature } \\
\text { Range }-35-70^{\circ} \mathrm{C} \\
\text { Accuracy } \pm 2 \% \\
\text { Resolution } 0.1^{\circ} \mathrm{C} \\
\text { Response time } 0.25 \mathrm{sec} \\
\\
\frac{\text { Humidity relative }}{\text { Range } 5-100 \%} \\
\text { Accuracy } \pm 2 \% \\
\text { Resolution } 1 \% \\
\text { Response time } 0.25 \mathrm{sec}\end{array}$ \\
\hline Lux meter (Lux) & Ix & $\begin{array}{c}\text { Range } 40,400,4000,40000,400000 \text { Lux } \\
\text { Accuracy } \pm 3 \% \\
\text { Resolution } 0.1 \text { Lux } \\
\text { Response Time } 0.25 \text { seconds } \\
\end{array}$ \\
\hline Thermography camera & Body temperature $\left({ }^{\circ} \mathrm{C}\right)$ & $\begin{array}{c}\text { Range }-20-1200^{\circ} \mathrm{C} \\
\text { Accuracy } \pm 2{ }^{\circ} \mathrm{C} \text { or } 2 \% \\
\text { Detector resolution } 320 \times 240(76,800 \text { pixels }) \\
\text { Resolution } 0.1^{\circ} \mathrm{C} \\
\text { Response Time } 0.25 \text { seconds }\end{array}$ \\
\hline Noise level (dB) & Noise (dB) & $\begin{array}{c}\text { Range } 0 \text { - } 130 \mathrm{~dB} \\
\text { Accuracy } \pm 2.0 \mathrm{~dB} \\
\text { Resolution } 0.1 \mathrm{~dB} \\
\text { Response Time } 0.25 \mathrm{~seconds}\end{array}$ \\
\hline
\end{tabular}

Figure 2, shows the distribution of ST, Light, Noise, $H$ and $\mathrm{THI}$ for the different typologies and thermal floors at different hours during the day. The higher $T_{d b}$ were found in the typologies X (warm) and VII and IX (mild) between 12:00 and 15:00, coinciding with the highest $S T$. The highest $R H$ was found in typology II (mild) and I and IV (Cold), and the lowest in typologies IX (mild) and X (warm). The most stable temperature ST during the 12 hours were found in the typologies III and V (Mild) and IV (cold). 
The Light was below 40 Ix in the typologies $\mathrm{V}$ and IX (mild) I and IV (cold) the most part of the day, indicating poor comfort conditions.. The noise levels were below $70 \mathrm{db}$ in all typologies except in the $\mathrm{V}$ one, in the first hours the day. $\mathrm{THI}$ in $\mathrm{VI}$ and $\mathrm{X}$ typologies in warm climate were all-time near to 80 , meaning thermal discomfort. In mild climate, the $T H I$ was near to 80 only between $12: 00$ to $16: 00$, while in the other typologies, the $\mathrm{THI}$ was close to 70 most of the time. The $H$ behavior was similar to the $T H I$ in all typologies; however, only in the typologies III (mild) and IV (cold) all-time, the $H$ were lower than 70 .

Table 6 Mean and standard deviation of $T_{d b}, R H, S T$, Light, Noise, $\mathrm{CH}_{4}, \mathrm{H}$ and $\mathrm{THI}$ for different construction typologies and thermal floor.

\begin{tabular}{|c|c|c|c|c|c|c|c|c|}
\hline $\begin{array}{l}\text { Thermal Floor } \\
\text { (MASL) }\end{array}$ & Tipology & $\begin{array}{l}T_{d b} \\
\left({ }^{\circ} \mathrm{C}\right)\end{array}$ & $\begin{array}{l}\mathrm{RH} \\
(\%)\end{array}$ & $\begin{array}{l}\text { ST } \\
\left({ }^{\circ} \mathrm{C}\right)\end{array}$ & $\begin{array}{l}\text { Light } \\
(\mathrm{Ix})\end{array}$ & $\begin{array}{l}\text { Noise } \\
\text { (db) }\end{array}$ & $\begin{array}{c}\mathrm{H} \\
\left(\mathrm{Kj} \mathrm{kg}^{-1}\right)\end{array}$ & THI \\
\hline Warm & $\mathrm{VI}$ & $29.76 \pm 2.52^{\mathrm{a}}$ & $61 \pm 8^{\mathrm{cd}}$ & $35.37 \pm 1.82^{\mathrm{a}}$ & $98.2 \pm 4.82^{\mathrm{a}}$ & $70.26 \pm 6.10^{a}$ & $72.98 \pm 4.04^{\mathrm{a}}$ & $79 \pm 2^{\mathrm{a}}$ \\
\hline$(0-1000)$ & $x$ & $30.35 \pm 4.22^{\mathrm{a}}$ & $57 \pm 10^{a}$ & $35.77 \pm 2.54^{a}$ & $78.3 \pm 3.42^{\mathrm{ab}}$ & $66.65 \pm 6.44^{\mathrm{ab}}$ & $74.48 \pm 7.86^{a}$ & $79 \pm 4^{a}$ \\
\hline \multirow{5}{*}{$\begin{array}{c}\text { Mild } \\
(1000-2000)\end{array}$} & II & $26.57 \pm 2.35^{\mathrm{ab}}$ & $72 \pm 3^{\mathrm{ab}}$ & $34.08 \pm 1.58^{\mathrm{ab}}$ & $48.35 \pm 1.84^{\text {cd }}$ & $66.69 \pm 7.38^{\mathrm{ab}}$ & $71.6 \pm 7.48^{\mathrm{ab}}$ & $77 \pm 3^{\mathrm{ab}}$ \\
\hline & III & $24.58 \pm 1.52^{\mathrm{bc}}$ & $70 \pm 3 a b c$ & $34.42 \pm 1.19^{a b}$ & $55.2 \pm 1.93^{\mathrm{bcd}}$ & $60.34 \pm 6.92^{b}$ & $63.28 \pm 5.10$ & $73 \pm 2^{\mathrm{bc}}$ \\
\hline & $\mathrm{v}$ & $27.32 \pm 2.72^{\mathrm{ab}}$ & $61 \pm 3^{\text {cd }}$ & $34.53 \pm 1.47^{\mathrm{ab}}$ & $45.3 \pm 1.61^{\text {cd }}$ & $68.91 \pm 6.78^{\mathrm{ab}}$ & $68.09 \pm 8.82^{\mathrm{abc}}$ & $76 \pm 3^{\mathrm{ab}}$ \\
\hline & VII & $27.07 \pm 4.57^{\mathrm{ab}}$ & $62 \pm 8^{\text {bcd }}$ & $35.07 \pm 2.46^{\mathrm{a}}$ & $67.31 \pm 2.12^{\mathrm{abc}}$ & $67.03 \pm 6.42^{\mathrm{ab}}$ & $68.14 \pm 11.12^{\mathrm{abc}}$ & $75 \pm 6^{\mathrm{ab}}$ \\
\hline & IX & $27.77 \pm 4.73^{\mathrm{ab}}$ & $62 \pm 10^{\mathrm{bcd}}$ & $35.37 \pm 2.31^{\mathrm{a}}$ & $48.3 \pm 1.35^{\mathrm{cd}}$ & $64.99 \pm 7.44^{\mathrm{abc}}$ & $68.84 \pm 9.60^{\mathrm{abc}}$ & $77 \pm 5^{\mathrm{ab}}$ \\
\hline \multirow{3}{*}{$\begin{array}{c}\text { Cold } \\
(2000-3000)\end{array}$} & 1 & $23.92 \pm 2.06^{\mathrm{bc}}$ & $76 \pm 8^{a}$ & $34.13 \pm 1.69^{\mathrm{ab}}$ & $10.73 \pm 1.32^{c}$ & $63.09 \pm 6.98^{\mathrm{bcd}}$ & $67.16 \pm 8.02^{\mathrm{abc}}$ & $72 \pm 3^{b c}$ \\
\hline & IV & $21.64 \pm 2.31^{c}$ & $68 \pm 5^{a b c}$ & $33.74 \pm 1.22^{c}$ & $25.23 \pm 1.75^{b}$ & $65.09 \pm 4.72^{\mathrm{abc}}$ & $53.80 \pm 6.22^{b}$ & $69 \pm 3^{c}$ \\
\hline & VIII & $24.45 \pm 2.44^{\mathrm{bc}}$ & $63 \pm 7^{\text {bcd }}$ & $33.83 \pm 1.82^{c}$ & $45.4 \pm 1.84^{\text {cd }}$ & $66.71 \pm 7.30^{\text {ab }}$ & $60.34 \pm 7.16^{\text {bcd }}$ & $72 \pm 3^{b c}$ \\
\hline
\end{tabular}

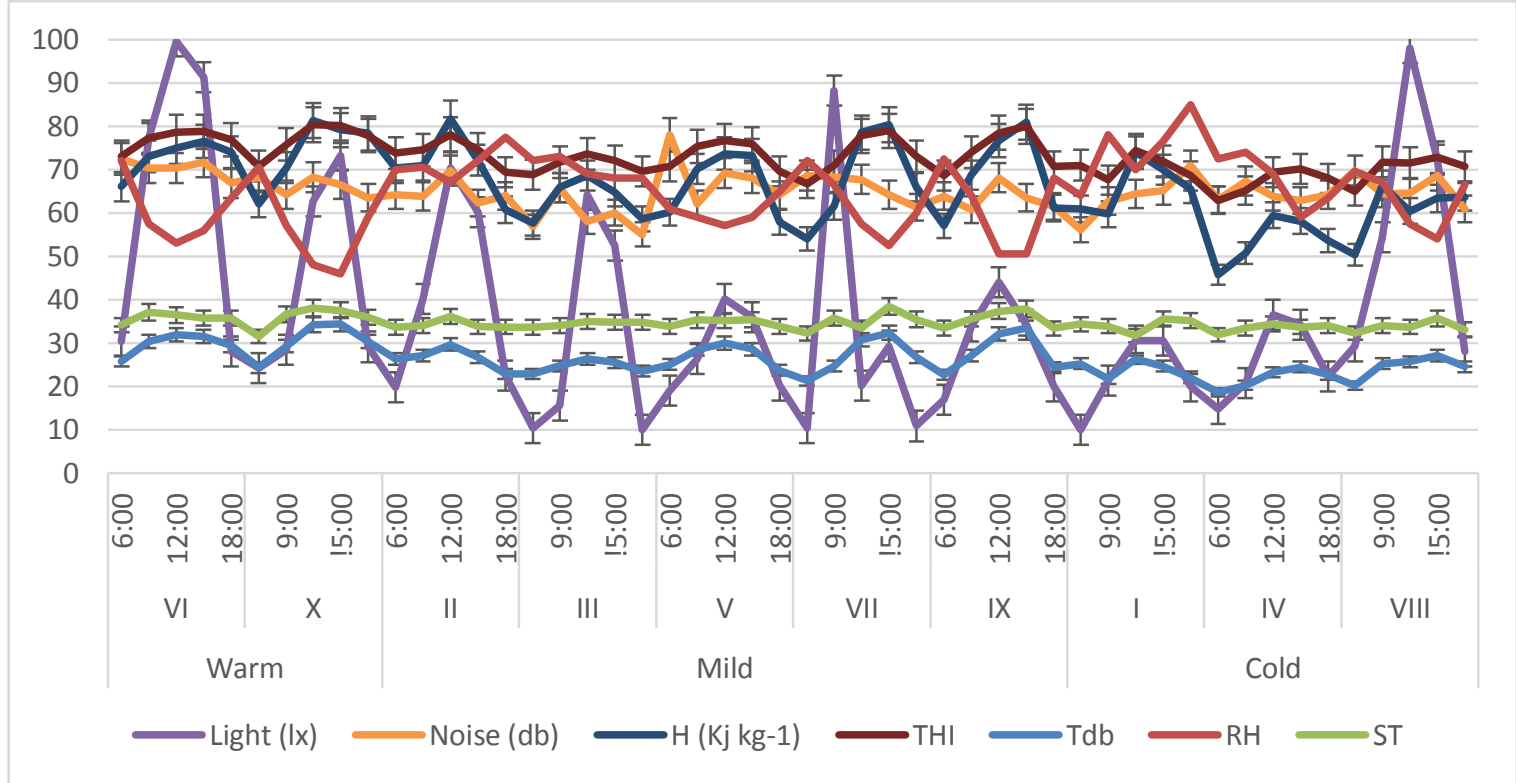

Figure 2 Distribution Light, Noise, $H, T H I$ and ST for different typologies at different hours during the day.

Table 7 shows the spatial distribution of light, Noise, and $T H I$ in the different typologies at 15:00 hours (when the typologies reach the highest values). Despite all typologies being refrigerated employing natural ventilation, most of the facilities presented $\mathrm{THI}$ above 70 in the day's hours with the highest temperatures, except for the typologies I, IV, and VIII that were in cold climates. Other Typologies, II, VI, and VII that were located in warm and mild climate have a good rate between ventilation area and total area, as shown in Table 1, which presents $T H I$ values over the thermal comfort limits. The I and IV in cold climate were the typologies that have the worse light intensity distribution.
Table 8 shows the overall comfort of each typology, in the function of parameters as Light Intensity, Noise, and THI, using a weighing matrix methodology, where the THI parameter has $50 \%$ of relative value, Ix $30 \%$, and Noise $20 \%$, using a classification of zero (0) for discomfort and five (5) for comfort. It was found that the typologies III and VIII in mild and warm climate were the ones that showed the best thermal comfort conditions for pig production. The Typologies I and IV in warm climate have a middle thermal comfort, due to the lack to improve the light intensity conditions in each of them. The other typologies don't have good conditions for thermal comfort, mainly due to $T H I$ values above the limits. 
Table 7 Typical Spatial Distribution (width and length in $\mathrm{m}$ ) of light (lx), Noise (db) and $T H I$ in different typologies.

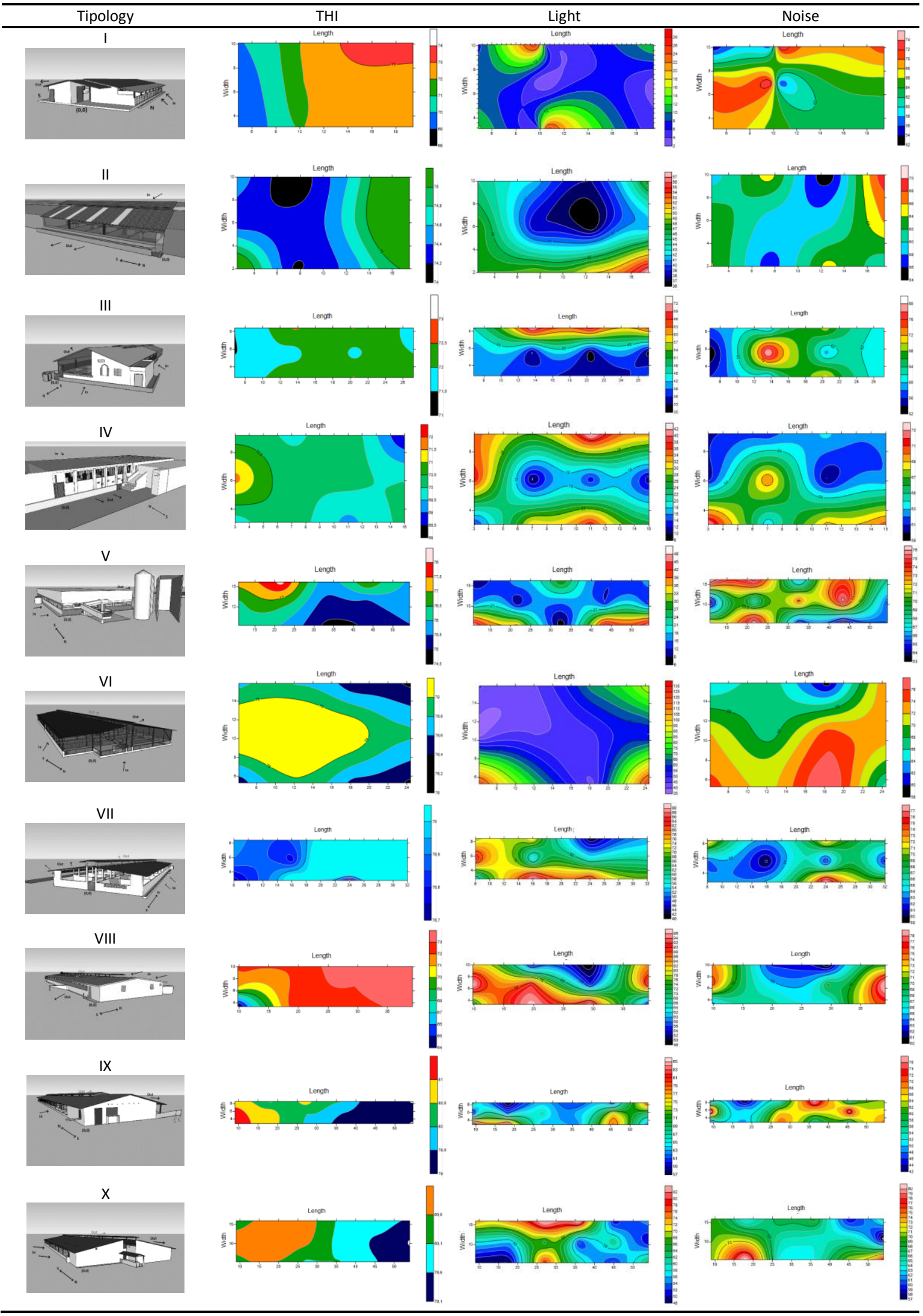


Table 8 Determination of overall comfort for diferents typologies.

\begin{tabular}{|c|c|c|c|c|c|}
\hline & Typology & Light & Noise & THI & Overall Comfort \\
\hline \multirow[t]{2}{*}{ Warm } & VI & Comfort & Discomfort & Thermal Discomfort & 1,5 - Low comfort \\
\hline & $x$ & Comfort & Comfort & Thermal Discomfort & 2,5 - Low comfort \\
\hline \multirow{5}{*}{ Mild } & II & Comfort & Comfort & Thermal Discomfort & 2,5 - Low comfort \\
\hline & III & Comfort & Comfort & Thermal Comfort & 5-High comfort \\
\hline & V & Comfort & Comfort & Thermal Discomfort & 2,5 - Low comfort \\
\hline & VII & Comfort & Comfort & Thermal Discomfort & 2,5 - Low comfort \\
\hline & IX & Comfort & Comfort & Thermal Discomfort & 2,5 - Low comfort \\
\hline \multirow{3}{*}{ Cold } & 1 & Discomfort & Comfort & Thermal Comfort & 3,5 - Middle comfort \\
\hline & IV & Discomfort & Comfort & Thermal Comfort & 3,5 - Middle comfort \\
\hline & VIII & Comfort & Comfort & Thermal Comfort & 5 - High comfort \\
\hline
\end{tabular}

\section{Conclusions}

In the state of Antioquia, the construction typologies assessment has shown that almost all typologies have been working on thermal discomfort, mainly because these facilities have $T H I$ above the allowed values. In these facilities, thermal control employing natural ventilation is not enough to achieve suitable $T H I$ values. The $T H I$ distribution, Noice, and light intensity are not homogeneus inside the facilities, having a mix of thermal comfort and discomfort zones. Typologies, especially in cold climates, have a good distribution of $T H I$ values, however, the light intensity distribution is not suitable for pork production. The results show that most of the current typologies are not suitable for pork production. To achieve a more efficient and friendly production, new typological designs and bioclimatic conditioning need to be studied.

\section{Acknowledgements}

Thanks to the Agroindustry Bioclimatic Lab of National University of Colombia - Medellin. To all the Antioquia's producers who participated in the research and allowed the collection of data in their commercial facilities.

\section{Conflict of Interest}

The authors declare that they have no known competing financial interests or personal relationships that could have appeared to influence the work reported in this paper.

\section{Funding}

This research did not receive any financial support.

\section{References}

Amaral PIS, Campos AT, Yanagi Junior T, CecchinD, Leite EM, Dias e Silva NC
(2020) Using sounds produced by pigs to identify thermoneutrality zones for thermal environment assessment ratios. Engenharia Agrícola. doi:10.1590/1809-4430-eng.agric.v40n3p266-271/2020

Barbari M, Conti L (2009) Use of different cooling systems by pregnant sows in experimental pen. Biosystems engineering 103:239-244.

Barbosa Filho JAD, Vieira FMC, Silva IJO, Garcia DB, Silva MAN, Fonseca BHF (2009) Transporte de frangos: caracterização do microclima na carga durante o inverno. Revista Brasileira de Zootecnia 38:2442-2446.

Barreto N, Zangeronimo M, Fialho E (2010) Physiological adaptations of pigs under thermal stress. Nutritime Electronic Journal 7:1197-1211.

Wegner B, Spiekermeier I, Nienhoff H, Große-Kleimann J, Rohn K, Meyer H, Plate H, Gerhardy H, Kreienbrock L, Beilage E, Kemper N, Fels M (2019) Status quo analysis of noise levels in pig fattening units in Germany. Livestock Science doi: 10.1016/j.livsci.2019.103847

Buffington DE, Collazo-Arocho A, Canton GH, Pitt D, Thatcher WW, Collier RJ (1981) Black globe-humidity index (BGHI) as a comfort Eq. for dairy cows. Trans. ASAE 24:711-714.

Bureau of Meteorology (2005) Commonwealth of Australia (ABN 92637533 532). http://www.bom.gov.au/info/thermal_stress/\#wbgt. Accessed on: June 26, 2020.

Carvalho CCS, Santos TC, Silva GC, Santos LV, Moreira SJM, Botelho LFR (2014) Animal and human thermal comfort in poultry houses. Brazilian semiarid. Braz. J. Agric. Environ. Eng. 18:769-773.

Carvalho Cinara da CS, Santos TC, Silva GC, Santos LV, Moreira SJM, Botelho LFR (2014) Animal and human thermal comfort in poultry houses in Brazilian semiarid. Brazilian Journal of Agricultural and Environmental Engineering 18:769-773.

Castrillón N, González V, Osorio JA, Montoya AP, Correa G (2020) Assessment of the methane emission for different typologies of fattening swine facilities in the department of Antioquia Colombia. Agronomy Research. doi: 10.15159/AR.20.108

Cecchin D, Campos A, Amaral P, Sousa F, Ferraz P, Hüther C, Campos A (2019) Behavior of swine hosted in facilities with different construction typologies. Journal of Animal Behaviour and Biometeorology 7:6-10.

Cecchin D, Campos AT, Cruz VF, Amaral PI, Freitas LCSR, Andrade RR (2017) Thermal environment in growing and finishing pig facilities of different building typologies. Journal of Animal Behaviour and Biometeorology 5:118123. 
Cecchin D, Ferraz PFP, Campos AT, Sousa FA, Amaral PIS, Castro JO, Conti L, da Cruz VMF (2019) Thermal comfort of pigs housed in different installations. Agronomy Research. doi: 10.15159/AR.19.117

Damasceno FA, Oliveira CEA, Ferraz GAS, Nascimento JAC, Osorio JA, Brandão LF (2019) Welfare and spatial distribution of noise levels in swine nursery. Revista Brasileira de Engenharia Agrícola e Ambiental. doi:10.1590/1807-1929/agriambi.v23n3p196-202

De Oliveira JAJ, de Souza SRL, da Cruz VF, Vicentin TA, Glavina ASG (2018) Development of an android APP to calculate thermal comfort indexes on animals and people. Computers and Electronics in Agriculture 151:175-184.

Dos Santos TC, Carvalho CDC, da Silva GC, Diniz TA, Soares TE, Moreira SDJM, Cecon PR (2018) Influence of the thermal environment on swine zootechnical behavior and performance. Journal of Agroveterinary Sciences 17:241-253.

Ferraz PFP, Gonzalez VC, Ferraz GAS, Damasceno FA, Osorio JA, Conti L (2020) Assessment of spatial variability of environmental variables of a typical house of laying hens in Colombia: Antioquia state Case. Agronomy Research. doi: 10.15159/AR.20.099

ICA (2019) National Livestock Census - 2018 https://www.ica.gov.co/areas/pecuaria/servicios/epidemiologiaveterinaria/censos-2016/censo-2018. Accessed on: January 12, 2021.

Kiefer C, de Moura M, da Silva E, dos Santos A, Silva C, da Luz M, Nantes C (2010) Responses of finishing pigs kept in different thermal environments. Brazilian Journal of Health and Animal Production 11:496-504.

Kiefer C, Meignen BCG, Sanches JF, Carrijo AS (2009) Response of growing swine maintained in different thermal environments. Anim Arch 51:55-64.

Machado S, Nääs I, Reis J, Caldara F, Santos R (2016) Sows and piglets thermal comfort: a comparative study of the tiles used in the farrowing housing. Engenharia Agrícola 36:996-1004.

Moura DJ (1999) Ventilação na suinocultura. In: SILVA I.J.O. Ambiência e qualidade na produção industrial de suínos. Piracicaba: FEALQ, pp149-179.

Poveda G (2004) The hydroclimatology of Colombia: A synthesis from the interannual scale to the diurnal scale. Colombian Academy of Exact, Physical and Natural Sciences Journal 29: 01-222.
Ramos-Freitas LCDS, Torres-Campos A, Schiassi L, Yanagi-Junior T, Cecchin D (2017) Fuzzy index for swine thermal comfort at nursery stage based on behavior. Dyna 84:201-207.

Requejo JM, Garrido-Izard M, Correa EC, Villarroel M, Diezma B. (2018) Pig ear skin temperature and feed efficiency: Using the phase space to estimate thermoregulatory effort. Biosystems Engineering 174:80-88.

Roller WL, Goldmn RF (1969) Response of swine to acute heat exposure. Trans. ASAE 12:164-169.

Sarubbi J, Rossi L, Moura D, Oliveira R, Maia A (2012) Nocturnal thermal comfort in facilities for growing fattening swines. Engenharia Agrícola 32:1034-1040.

Schiassi L, Tadayuki Y, Damasceno FA, Osorio JA, Machado NS (2012). Fuzzy Modeling Applied to The Welfare of Poultry Farms Workers. Dyna 79:127135.

Thom EC (1958) Cooling Degree: Day Air Conditioning. Heating, And Ventilating. Transaction of the American Society of Heating 55:65-72.

Toniolli R, Guimarães D, Araújo L, Cantanhêde L, Barros T, Dias A (2014) Influence of thermal stress on the reproduction and production of male pigs. Animal Science 24:28-40.

Vieira R, Oliveira K, de Paula S, Martins J (2010) Comfort index in the evaluation of animal welfare of swine breeders in different rearing systems. Nucleus Animalium 2:1-8.

Vélez E, García G, Barrios D (2018) Exploratory study on the production and commercialization of pork in the Aburrá Valley, Antioquia (Colombia). Journal of the Faculty of Veterinary Medicine and Zootechnics 65:220-234.

Zanetoni T, Barbari M, Conti L, Rossi G, Baêta FC, Vilela MO, Teles CGS, Andrade RR (2019) Alternative form to obtain the black globe temperature from environmental variables H.H.R. Agronomy Research. doi: 10.15159/AR.19.109

Zonderland J, Cornelissen AHM, Fillerup M, Spoolder HAM (2008) Sual acuity of pigs at different light intensities. Applied Animal Behaviour Science. doi: 10.1016/j.applanim.2007.05.010 